\title{
High antimicrobial resistance in Salmonella spp. and Escherichia coli isolates from swine fecal samples submitted to a veterinary diagnostic laboratory in Colombia
}

\author{
Alta resistencia antimicrobiana en aislamientos de Salmonella spp. y Escherichia coli a partir de \\ muestras fecales porcinas enviadas a un laboratorio de diagnóstico veterinario en Colombia
}

\section{Alta resistência antimicrobiana em isolados de Salmonella $\underline{\text { spp}}$. e Escherichia coli isoladas de amostras fecais de suínos enviadas a um laboratório de diagnóstico veterinário na Colômbia}

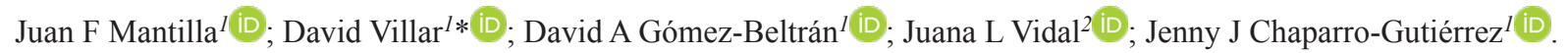

${ }^{1}$ Grupo CIBAV, Escuela de Medicina Veterinaria, Facultad de Ciencias Agrarias, Universidad de Antioquia, Medellín, Colombia.

${ }^{2}$ Unidad de Diagnóstico Facultad de Ciencias Agrarias, Universidad de Antioquia, Medellín, Colombia.

To cite this article:

Mantilla JF, Villar D, Gómez-Beltrán DA, Vidal JL, Chaparro-Gutiérrez JJ. High antimicrobial resistance in Salmonella spp. and Escherichia coli isolates from swine fecal samples submitted to a veterinary diagnostic laboratory in Colombia. Rev Colomb Cienc Pecu 2022; 35(1): 26-35. DOI: https://doi.org/10.17533/udea.rccp.v35n1a03

\begin{abstract}
Background: Commensal microflora such as Escherichia coli and Enterococcus spp. are representative indicators of antimicrobial resistance (AMR) as they are part of the normal intestinal microflora and can acquire and disseminate AMR to pathogenic or zoonotic bacteria like Salmonella spp. Objective: To investigate the state of AMR among E. coli and Salmonella spp., potential pathogens in humans, isolated from cecal contents of pigs submitted to a veterinary diagnostic laboratory in Colombia from 2016 to 2019. Methods: Susceptibility testing was conducted using the Kirby-Bauer disk diffusion method according to the Clinical and Laboratory Standards Institute guidelines for antimicrobial zone diameter breakpoints. An E. coli strain (ATCC 25922) was used as the quality control organism. Isolates showing resistance to three or more antimicrobial classes were classified as multidrug-resistant (MDR) as defined by a joint group of the European Centre for Disease prevention and Control and the Center for Disease Control and Prevention of the USA. Results: A total of 112 E. coli and 192 Salmonella spp. colonies were isolated from 557 samples received between 2016 and 2019. In order of decreasing frequency, E. coli was resistant to tetracycline (100\%), sulfamethoxazol-trimethoprim $(97.5 \%)$, amoxicillin $(86.4 \%)$, enrofloxacin $(82.6 \%)$, tylosin $(82.1 \%)$, doxycycline (59\%), neomycin $(50 \%)$, ciprofloxacin $(45.5 \%)$, ceftiofur $(35 \%)$, gentamicin $(30 \%)$, tilmicosin (29\%), and fosfomycin (12.5\%). When compared with E. coli, Salmonella spp. was generally resistant to the same agents with slightly less resistance (between 10-30\%) to eight of the antimicrobials tested. Salmonella spp. showed $<20 \%$ resistance to three antimicrobials, as follows: neomycin (17\%), gentamicin (16\%), and fosfomycin (14\%). Multi-resistance occurred in $68.7 \%(77 / 112)$ of E. coli and 70.3\% (135/192) of Salmonella spp. isolates. Resistance of Salmonella spp. was alarming to all the critically important antimicrobials tested: fluoroquinolones (enrofloxacin, ciprofloxacin), ceftiofur (thirdgeneration cephalosporin), and macrolides (tylosin). Conclusions: According to our results, there is a high level of multidrug resistance (MDR) in E. coli and Salmonella spp. It is necessary to implement a nationwide antimicrobial resistance monitoring program in Colombia, together with proper antimicrobial prescribing guidelines for pigs. The indiscriminate use of antimicrobial growth promoters by the swine industry is generating widespread bacterial resistance and should be discontinued.
\end{abstract}

Received: December 23, 2020; accepted: March 28, 2021

*Corresponding author. Carrera 75 No. 65-87, Medellín, Antioquia, Colombia (South America). Tel.: +57-317-804-7381. Email: david.villar@udea.edu.co

\section{(i) (2) (2)}

BY NC SA This work is licensed under a Creative Commons Attribution-NonCommercial-ShareAlike 4.0 International License.

(c) 2022 Universidad de Antioquia. Publicado por Universidad de Antioquia, Colombia. 
Keywords: antibiotic; antimicrobial resistance; bacterial resistance; Escherichia coli; multi-resistance; multi-resistant

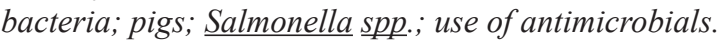

\section{Resumen}

Antecedentes: La microflora comensal como Escherichia coli y las especies de Enterococcus se eligen típicamente como indicadores representativos de la resistencia antimicrobiana (AMR), ya que forman parte de la flora intestinal normal y pueden adquirir y diseminar AMR a bacterias patógenas o zoonóticas como Salmonella spp. Objetivo: Investigar el estado de la AMRentre E. coli y Salmonella spp., ambos patógenos potenciales en humanos, aislados del contenido cecal de cerdos sometidos a un laboratorio de diagnóstico veterinario en Colombia entre 2016 y 2019. Métodos: Las pruebas de susceptibilidad se realizaron utilizando el método de difusión en disco Kirby-Bauer de acuerdo con las pautas del Instituto de Estándares Clínicos y de Laboratorio para los puntos de corte del diámetro de la zona antimicrobiana. Se utilizó una cepa de E. coli (ATCC 25922) como organismo de control de calidad. Los aislamientos que mostraron resistencia a tres o más clases de antimicrobianos se clasificaron como multirresistentes (MDR) según la definición de un grupo conjunto del Centro Europeo para la Prevención y Control de Enfermedades y el Centro para el Control y Prevención de Enfermedades de los EE. UU. Resultados: Un total de 112 colonias de E. coli y 192 de Salmonella spp. se aislaron de 557 muestras recibidas entre 2016 y 2019. En orden decreciente de frecuencia, la resistencia a $E$. coli fue: tetraciclina (100\%), sulfametoxazol-trimetoprima (97,5\%), amoxicilina (86,4\%), enrofloxacina (82,6\%), tilosina $(82,1 \%)$, doxiciclina (59\%), neomicina (50\%), ciprofloxacina $(45,5 \%)$, ceftiofur (35\%), gentamicina (30\%), tilmicosina (29\%) y fosfomicina (12,5\%). En comparación con E. coli, la Salmonella spp. fue generalmente resistente a los mismos agentes, con una resistencia ligeramente menor (entre 10-30\%) a ocho de los antimicrobianos. La Salmonella spp. mostró resistencia por debajo del $20 \%$ a tres antimicrobianos, asi: neomicina (17\%), gentamicina (16\%), y fosfomicina (14\%). Se observó multirresistencia en el $68,7 \%$ (77/112) de los aislamientos de E. coli y el 70,3\% (135/192) de Salmonella spp. La resistencia observada de Salmonella spp. fue alarmante para todos los antimicrobianos de importancia crítica ensayados: fluoroquinolonas (enrofloxacina, ciprofloxacina), ceftiofur (cefalosporina de tercera generación) y macrólidos (tilosina). Conclusiones: Nuestros resultados indican que existe un alto nivel de multirresistencia en E. coli and Salmonella spp. Se requiere implementar un programa nacional de monitoreo de la resistencia a los antimicrobianos en Colombia, al igual que pautas apropiadas de prescripción de antimicrobianos para cerdos. El uso indiscriminado por la industria porcina de promotores de crecimiento de tipo antibiotico está generando resistencia bacteriana generalizada y debe suspenderse.

Palabras clave: antibiótico; bacteria multirresistente; cerdos; Escherichia coli; multirresistencia; resistencia antimicrobiana; resistencia bacteriana; Salmonella spp.; uso de antimicrobianos.

\section{Resumo}

Antecedentes: Flora comensal como espécies de Escherichia coli e Enterococcus são tipicamente escolhidas como indicadores representativos de la resistência antimicrobiana (AMR), pois fazem parte da flora intestinal normal e podem adquirir e disseminar AMR a bactérias patogênicas ou zoonóticas como Salmonella spp. Objetivo: Investigar o estado da AMR entre $E$. coli e Salmonella spp. isolados do conteúdo cecal de porcos colombianos submetidos ao Laboratório de Diagnóstico Veterinário de 2016 a 2019, ambos sendo patógenos potenciais em humanos. Métodos: O teste de suscetibilidade foi conduzido usando o método de difusão em disco Kirby-Bauer de acordo com as diretrizes do Instituto de Padrões Clínicos e Laboratoriais para pontos de quebra de diâmetro da zona antimicrobiana. A cepa de E. coli (ATCC 25922) foi usada como organismo de controle de qualidade. Os isolados que apresentam resistência a três ou mais classes de antimicrobianos foram classificados como multirresistentes (MDR), conforme definido por um grupo conjunto do Centro Europeu para Prevenção e Controle de Doenças e Centro para Controle e Prevenção de Doenças dos EUA. Resultados: Um total de 112 E. coli e 192 Salmonella spp. foram isolados de 557 amostras submetidas entre 2016 e 2019. Em ordem decrescente de frequência, a resistência a $E$. coli foi: tetraciclina (100\%), sulfametoxazol-trimetoprim (97,5\%), amoxicilina $(86,4 \%)$, enrofloxacina $(82,6 \%)$, tilosina $(82,1 \%)$, doxiciclina (59\%), neomicina (50\%), ciprofloxacina (45,5\%), ceftiofur (35\%), gentamicina (30\%), tilmicosina (29\%) e fosfomicina (12,5\%). Quando comparada com E. coli, Salmonella spp. foi geralmente resistente aos mesmos agentes com resistência ligeiramente menor (entre 10-30\%) a oito dos antimicrobianos. Apenas três antimicrobianos apresentaram resistência a Salmonella spp. abaixo de $20 \%$ da seguinte forma: neomicina (17\%), gentamicina (16\%) e fosfomicina (14\%). Multi-resistência ocorreu em 68,7\% (77/112) de E. coli e 70,3\% (135/192) de Salmonella spp. isolados. Resistência de Salmonella spp. foi alarmante para todos os antimicrobianos criticamente importantes testados: fluoroquinolonas (enrofloxacina, ciprofloxacina), ceftiofur (cefalosporina de terceira geração) e macrolídeos (tilosina). Conclusões: Esses resultados indicam um alto nível de resistência a múltiplos medicamentos (MDR) e que um Programa Nacional de Monitoramento da Resistência Antimicrobiana é necessário para a Colômbia, juntamente com a implementação de diretrizes de prescrição de antimicrobianos para suínos. $\mathrm{O}$ uso indiscriminado de antimicrobianos para promoção de crescimento na indústria suína está claramente promovendo resistência generalizada e deve ser interrompido.

Palavras-chave: antibiótico; bactérias multirresistentes; Escherichia coli; multirresistência; resistência antimicrobiana; resistência bacteriana; Salmonella spp., uso de antimicrobianos; suínos. 


\section{Introduction}

The prevalence and extent of antimicrobial resistance (AMR) in an animal herd is directly correlated to the total volume of antimicrobial usage (Angulo et al., 2004). In swine, where there is heavy use of antibiotics in intensive farming systems, this results in a large reservoir of antimicrobial-resistant bacteria. This is particularly so in countries like Colombia, where antimicrobials continue to be used as growth promoters in swine feed.

The prevalence and degree of AMR found in indicator bacteria in the fecal microflora of swine is a good indicator of the selection pressure of antimicrobial usage. Commensal microflora, like generic E. coli and Enterococcus spp. are typically chosen as representative indicators of AMR as they are part of the normal microflora and can acquire and disseminate resistance to pathogenic or zoonotic bacteria (Van den Bogaard et al., 2000). Thus, they can be used to compare levels of resistance between pig populations, with no resistance being the ideal goal. Medical doctors have used the analogy of not detecting resistance in indicator $E$. coli in healthy children to having "normal blood pressure" and "low cholesterol levels" (Lester et al., 1990). Since 2014, monitoring of AMR in indicator $E$. coli from food-producing animals and their food products has been mandatory under the European legislation (EFSA, 2019). There is concern that resistant bacteria may be selected in the intestinal microflora of swine contaminating food in the slaughtering process and then transferring its resistance genes to other bacteria in the human gut. In addition, the presence of E. coli on pig carcasses during slaughter is considered a reliable indicator of how good are the hygiene practices in the slaughter line (Belluco et al., 2005).

With regards to the genus Salmonella, pork has traditionally been blamed with food-borne illnesses caused by Salmonella spp. so numerous countries have established monitoring systems to report prevalence of Salmonella spp. and its antimicrobial susceptibility (Haley et al., 2012;
Kadykalo et al., 2018; Kidsley et al., 2018). In recent decades, with the virtual elimination of Cysticercus cellullosae and Trichinella from pork in most developed countries, the highest concern for the safety of pork has turned to bacterial contamination, particularly with Salmonella species. Several Salmonella serovars isolated from pigs are considered important for public health, including Cholera suis, enteritidis, and typhimurium (EFSA, 2019). In addition, the genus Salmonella is also known for its potential to develop multi-drug resistance. For example, in a survey analyzing 7,788 fecal samples with an overall prevalence of $7.2 \%$ in the USA, the proportion of MDR isolates was $57.7 \%$ (Haley et al., 2012). A recent study in Colombia evaluated the overall prevalence in 21 farms across the country showing 7.6\% (feces), 8.7\% (rectal swabs), and a 38.1\% seroprevalence (Giraldo-Cardona et al., 2019). According to another research conducted in 31 Colombian slaughterhouses, prevalence of slaughtered pigs infected with species of Salmonella spp. in lymph nodes ranged between 4.2 and $60 \%$ (Ayala-Romero et al., 2018). Because this test is a sensitive test at the individual animal level, it suggests that widespread infection is already present at the primary production site. It is necessary to conduct further studies at the moment of slaughter and in the slaughterhouse environment, as these represent a greater risk to public health.

Countries such as Canada and the United States have national surveillance programs to monitor resistance trends among specific pathogen indicator species through both active and passive means (Haley et al., 2012; Karp et al., 2017; Kadykalo et al., 2018). Passive surveillance using data from veterinary diagnostic laboratories have limitations as they may not be representative of the general bacterial populations. On the other hand, they may be important because clinically ill animals are direct targets of antimicrobial treatments and so have the greatest selective pressure. 
In Colombia, there is a lack of information on the occurrence of antimicrobial resistance and, given the extended use of antimicrobials as growth promoters, studies are urgently needed to evaluate the current situation. Therefore, the aim of this study was to investigate the state of AMR in generic E. coli and Salmonella spp. isolated from cecal contents of pigs submitted to a veterinary diagnostic laboratory in Colombia from 2016 to 2019.

\section{Materials and Methods}

Results of antimicrobial susceptibility test were obtained at the Laboratorio de Diagnóstico Veterinario of the Universidad de Antioquia from fecal samples of swine cases submitted between 2016 and 2019. Susceptibility testing was conducted using the Kirby-Bauer disk diffusion method according to the Clinical and Laboratory Standards Institute guidelines for antimicrobial zone diameter breakpoints (CLSI, 2018). The antimicrobials (Oxoid, Hampshire, United Kingdom) tested were: amoxicillin (10 ug), ceftiofur (30 ug), ciprofloxacin (5 ug), florfenicol (30 ug), gentamicin (10 ug), sulfamethoxazol/ trimethoprim $(25 \mathrm{ug})$, tetracycline $(30 \mathrm{ug})$, enrofloxacin (5 ug), doxycyclin (30 ug), neomycin (30 ug), and tylosin (30 ug). E. coli strain ATCC 25922 was used as the CLSI quality control strain for antimicrobial susceptibility testing. Isolates showing resistance to three or more antimicrobial classes were classified as multidrug-resistant (MDR) as defined by a joint group of the European Centre for Disease prevention and Control and the Center for Disease Control and Prevention of the USA (Magiorakos et al., 2012).

On the day of arrival, $10 \mathrm{~g}$ of fecal material was suspended in $7 \mathrm{~mL}$ of $0.1 \%$ sterile peptone water and mixed before $1 \mathrm{~mL}$ of the mixture was extracted and centrifuged. The homogenate was plated onto MacConkey agar (Oxoid, Thermofisher Scientific, Hampshire, United Kingdom) and incubated at $37{ }^{\circ} \mathrm{C}$ for $24 \mathrm{~h}$.
Lactose positive presumptive $E$. coli colonies were subcultured onto sheep blood agar (Oxoid, Themofisher Scientific, Hampshire, United Kingdom) and incubated at $37{ }^{\circ} \mathrm{C}$ for $24 \mathrm{~h}$. The isolates on nutrient agar were subjected to an indole test for $E$. coli identification. For Salmonella spp. isolation and colony identification, the steps followed the sequence shown in Figure 1.

\section{Statistical analysis}

The data were entered into Excel 2010 and descriptive statistics used to assess frequency of resistance. Since few results were classified as intermediate (neither susceptible nor resistant to the antimicrobial), for discussion purposes they were reclassified in the resistant category.

\section{Results}

A total of 557 fecal samples were submitted between 2016 and 2019 from which 112 and 192 E. Coli and Salmonella spp. colonies were isolated, respectively. Results of antimicrobial resistance and susceptibility patterns of the isolated E. coli and Salmonella spp. colonies are presented in Tables 1 and 2. Not all antibiotics were tested on all strains. For E. coli, the percentage resistance, in order of decreasing prevalence was: tetracycline $(100 \%)$, sulfamethoxazol-trimethoprim $(97.5 \%)$, ampicillin $(95.4 \%)$, amoxycillin $(86.4 \%)$, enrofloxacin $(82.6 \%)$, tylosin $(82.1 \%)$, doxycycline $(59 \%)$, neomycin $(50 \%)$, ciprofloxacin $(45.5 \%)$, ceftiofur $(35 \%)$, gentamicin $(30 \%)$, tilmicosin $(29 \%)$, fosfomycin (12.5\%). With regards to Salmonella spp., the decreasing order of resistance prevalence was: tetracycline $(100 \%)$, tylosin $(89 \%)$, florfenicol (84.4\%), tilmicosin $(80 \%)$, doxycyclin $(76.5 \%)$, enrofloxacin $(72 \%)$, sulfamethoxazol-trimethoprim (68.5\%), ampicillin (66.7\%), amoxicillin (63.6\%), ciprofloxacin (29.5\%), ceftiofur $(27.4 \%)$, neomycin $(17 \%)$, gentamicin $(16 \%)$, fosfomycin $(14 \%)$. Multi-drug resistance to three or more classes of antimicrobials was observed in $68.7 \%(77 / 112)$ of the E. coli isolates, and it was $70.3 \%$ (135/192) for the Salmonella spp. isolates. 


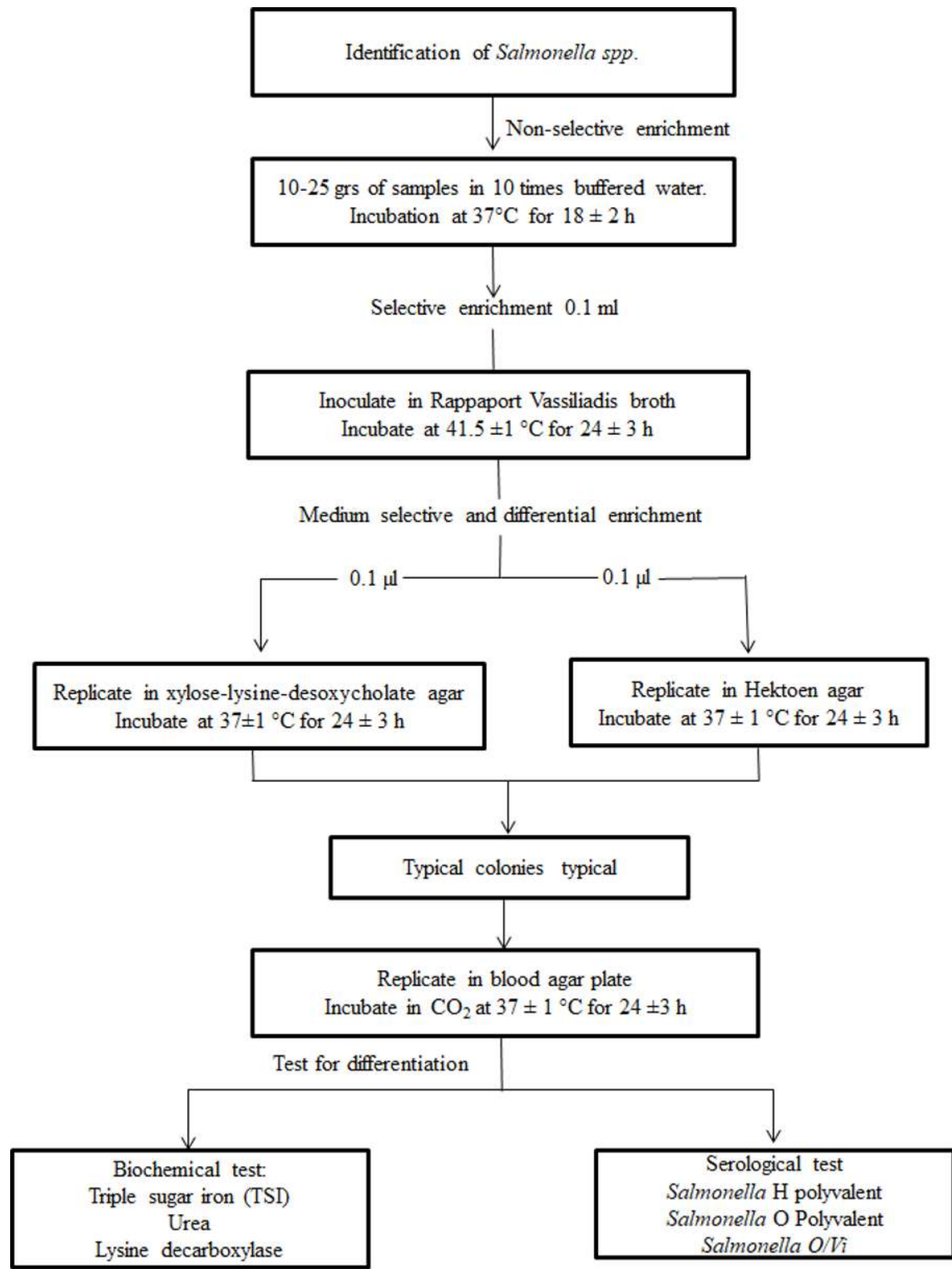

Figure 1. Steps used to identify Salmonella spp. from fecal samples. 
Table 1. Susceptibility of generic E. coli isolated from 112 swine fecal samples to different antimicrobial agents.

\begin{tabular}{lccccccc}
\hline \multirow{2}{*}{ Antimicrobial agent } & \multicolumn{2}{c}{ Resistant } & \multicolumn{2}{c}{ Intermediate } & \multicolumn{2}{c}{ Susceptible } \\
\cline { 2 - 7 } & $\mathbf{N}$ & $\mathbf{n}$ & $\mathbf{\%}$ & $\mathbf{n}$ & $\mathbf{\%}$ & $\mathbf{n}$ & $\mathbf{\%}$ \\
\hline Enrofloxacin & 86 & 51.0 & 59.3 & 20.0 & 23.3 & 15.0 & 17.4 \\
Sulfamethoxazol- Trimethoprim & 79 & 77.0 & 97.5 & 0.0 & 0.0 & 2.0 & 2.5 \\
Ciprofloxacin & 68 & 31.0 & 45.6 & 0.0 & 0.0 & 37.0 & 54.4 \\
Gentamicin & 67 & 19.0 & 28.4 & 1.0 & 1.5 & 47.0 & 70.1 \\
Florfenicol & 63 & 47.0 & 74.6 & 4.0 & 6.3 & 12.0 & 19.0 \\
Amoxycillin & 59 & 49.0 & 83.1 & 2.0 & 3.4 & 8.0 & 13.6 \\
Ceftiofur & 57 & 15.0 & 26.3 & 5.0 & 8.8 & 37.0 & 64.9 \\
Fosfomycin & 48 & 6.0 & 12.5 & 0.0 & 0.0 & 42.0 & 87.5 \\
Tetracycline & 46 & 46.0 & 100.0 & 0.0 & 0.0 & 0.0 & 0.0 \\
Tylosin & 28 & 22.0 & 82.1 & 0.0 & 0.0 & 6.0 & 17.9 \\
Tilmicosin & 24 & 7.0 & 29.2 & 0.0 & 0.0 & 17.0 & 70.8 \\
Ampicillin & 21 & 20.0 & 95.2 & 0.0 & 0.0 & 1.0 & 4.8 \\
Neomycin & 20 & 9.0 & 45.0 & 1.0 & 5.0 & 10.0 & 50.0 \\
Doxycycline & 17 & 7.0 & 41.2 & 3.0 & 17.6 & 7.0 & 41.2 \\
\hline
\end{tabular}

Table 2. Susceptibility of Salmonella spp. isolated from 192 swine fecal samples to different antimicrobial agents.

\begin{tabular}{lccccccc}
\hline \multirow{2}{*}{ Antimicrobial agent } & \multicolumn{4}{c}{ Resistant } & \multicolumn{2}{c}{ Intermediate } & \multicolumn{2}{c}{ Susceptible } \\
\cline { 2 - 7 } & $\mathbf{N}$ & $\mathbf{n}$ & $\mathbf{\%}$ & $\mathbf{n}$ & $\mathbf{\%}$ & $\mathbf{n}$ & $\mathbf{\%}$ \\
\hline Enrofloxacin & 162 & 66.0 & 40.7 & 51.0 & 31.5 & 45.0 & 27.8 \\
Sulfamethoxazol- Trimethoprim & 143 & 97.0 & 67.8 & 1.0 & 0.7 & 45.0 & 31.5 \\
Florfenicol & 141 & 117.0 & 83.0 & 2.0 & 1.4 & 22.0 & 15.6 \\
Ciprofloxacin & 132 & 22.0 & 16.7 & 17.0 & 12.9 & 93.0 & 70.5 \\
Gentamicin & 101 & 12.0 & 11.9 & 4.0 & 4.0 & 85.0 & 84.2 \\
Fosfomycin & 100 & 12.0 & 12.0 & 2.0 & 2.0 & 86.0 & 86.0 \\
Amoxicillin & 99 & 61.0 & 61.6 & 2.0 & 2.0 & 36.0 & 36.4 \\
Ceftiofur & 62 & 13.0 & 21.0 & 4.0 & 6.5 & 45.0 & 72.6 \\
Neomycin & 53 & 6.0 & 11.3 & 9.0 & 17.0 & 44.0 & 83.0 \\
Ampicillin & 39 & 26.0 & 66.7 & 0.0 & 0.0 & 13.0 & 33.3 \\
Tetracycline & 39 & 39 & 100.0 & 0.0 & 0.0 & 0.0 & 0.0 \\
Tylosin & 27 & 24.0 & 88.9 & 1.0 & 3.7 & 2.0 & 7.4 \\
Cefalothin & 23 & 7.0 & 30.4 & 2.0 & 8.7 & 14.0 & 60.9 \\
Doxycycline & 17 & 12.0 & 70.6 & 1.0 & 5.9 & 4.0 & 23.5 \\
Tilmicosin & 10 & 7.0 & 70.0 & 1.0 & 10.0 & 2.0 & 20.0 \\
\hline
\end{tabular}




\section{Discussion}

The aim of this study was to investigate the frequency of AMR among E. coli and Salmonella spp. isolates from pig feces submitted to the Laboratorio de Diagnóstico Veterinario of the Universidad de Antioquia, Colombia. A major finding was the extremely high level of resistance $(70-100 \%)$ in both bacteria to tetracycline, doxycycline, sulfomethoxazol-trimethoprim, florfenicol, tylosin and enrofloxacin. The overall frequency of $E$. coli resistance to the antimicrobials with the highest resistance levels was even higher to that reported by the southern and eastern European countries in 2017 (EFSA, 2019). For example, when comparing the results of our study to Spain, the overall resistance in decreasing order of frequency was: tetracycline (100 vs $88.8 \%$ ), sulfamethoxazole (100 vs 63.6\%) trimethoprim (100 vs $60.6 \%$ ), ampicillin (95.4 vs $77.1 \%$ ), and ciprofloxacin (45.5 vs $44.7 \%$ ). In Spain, $60 \%$ of the $E$. coli isolates were MDR, being one of the countries in Europe with the largest number of MDR E. coli, with an overall mean of $34.9 \%$ for all the EU countries, ranging from $3.3 \%$ in Norway up to $82.5 \%$ in Cyprus. In our study, MDR for $E$. coli was $68.7 \%$ (higher than the $60 \%$ for Spain). When this resistance pattern is compared with the amount of antimicrobials used in pigs for the most common clinical conditions in Europe, a clear association becomes apparent. For respiratory diseases, $88 \%$ of the treatments mentioned were non-critically important antimicrobials (CIA), mostly tetracyclines $(47 \%)$ and penicillins $(21 \%)$ (De Briyne et al., 2014). These were followed by macrolides such as tylosin (10\%), and potentiated sulphonamides $(8 \%)$. For diarrhea, polymyxin (mostly colistin) was reported to be used 30\% of the times, followed by macrolides (10\%), potentiated sulfonamides $(9 \%)$, fluoroquinolones $(8 \%)$, and tiamulin $(7 \%)$.

There are no similar studies in Colombia reporting the overall use of antimicrobials in pigs, but considering that resistant trends were closely similar to those in Spain, it is likely that the type of antimicrobials used for the most common clinical conditions are similar. In addition, Colombian legislation does not compel feed companies to declare in the label of their products the type of growth promoters used; thus, it is likely that antimicrobials with the highest level of resistance (i.e., tetracycline, sulfamethoxazole-trimethoprim, tylosin) are used as growth promoters. In a systematic review of the most common isolated resistant pathogens from different food animals in Colombia, E. coli and Salmonella spp. were the most common bacteria showing resistance to beta-lactams, macrolides (tylosin) and tetracycline (Arenas and Moreno-Melo, 2018). In our findings, the observed high frequency of resistance to amoxicillin ( $86.4 \%$ for E. coli) could be explained by high usage of beta-lactams and also from co-selection of genes encoding $\square$-lactamase production, which are often located on the same plasmid as the genes for tetracycline resistance (Nijsten et al., 1996). Before colistin was considered a CIA by WHO (WHO, 2017), the relative mention of use of CIA to non-CIA in pigs was about $20 \%$ in Europe, with macrolides and fluoroquinolones accounting for the main groups suggested to be restricted in pigs in those countries that still used them widely (De Briyne et al., 2014).

With regards to Salmonella spp., the resistance pattern observed closely mirrored that for E. coli, but it tended to have lower resistance to some antimicrobials. When comparing our results to those of Spain in 2017, the overall frequency in decreasing order of frequency was: tetracycline (100 vs $75 \%$ ), sulfamethoxazole ( 68.5 vs $72 \%$ ), ampicillin (66.7 vs 67.1\%), ciprofloxacin (29.5 vs $20.7 \%$ ), and gentamicin (16 vs 9.8\%; ESFA, 2019). In their report, an overall $51.3 \%$ of Salmonella spp. isolates were MDR, but in our study $70.3 \%$ of the isolates were MDR, making them even more dangerous from a potential zoonotic standpoint than susceptible strains. A recent study in Colombia determined Salmonella spp. prevalence and antimicrobial resistance pattern from healthy pig fecal and swab samples, finding not so high resistance against some of the antimicrobials that we tested, such as ampicillin (33 vs 66.7\%), ciprofloxacin (11.1 vs $29.5 \%$ ), and trimethropimsulfametoxazole (50 vs 68.5\%; Giraldo-Cardona et $a l ., 2019)$. The higher resistance found in our study could be explained by the fact that our samples did not represent the general swine population and most 
samples submitted to the diagnostic laboratory probably came from clinically ill animals exposed to antimicrobial treatments.

The emergence of antibiotic resistance in non-typhoidal Salmonella spp. associated with antimicrobial use in pig production has been well documented. Campos et al., (2019) highlighted the contribution of different drivers to the overall resistance burden. Their review found that acquisition of resistance mechanisms to antibiotics with the highest resistance in our study (amoxicillin, tetracycline, sulphonamides) was relevant for their potential role in co-selection of pig-related MDR Salmonella clones and further transmission to humans. They concluded that "the pig production setting can be a relevant reservoir of successful and worldwide emergent MDR pigrelated Salmonella serotypes/clones, enriched with different features (e.g., metal/biocides tolerance genes) besides genes conferring resistance to critical antibiotics, which might spread to humans through the food chain".

The high bacterial resistance observed in pig fecal samples calls for a more rational usage of antimicrobials and the implementation of policies to safeguard their therapeutic efficacy and minimize public health risk. A national surveillance program should also be started to monitor antimicrobial resistance as part of the FAO, WHO, and OIE global initiatives. Colombia should observe WHO recommendations and restrict the growth promotion use of medically important antimicrobials in food-producing animals (Aidara-Kane et al., 2018). Guidelines on the prudent use of antimicrobials have been implemented in various swine producing countries (Magnusson et al., 2019; Cutler et al., 2020) and it is of utmost necessity to implement them in Colombia. Those guidelines should provide recommendations on the most common antimicrobials prescribed by veterinarians, starting with ways to prevent and control the underlying causes of disease by adopting good management and husbandry practices (it has long been recognized that the best response to antimicrobials is obtained under poor hygiene conditions).
A proof that guidelines and control strategies work is that countries such as Denmark and Australia are now successfully raising pigs with little reliance on antimicrobials.

In conclusion, our results indicate there is a high level of multi-drug resistance (MDR) in Colombia. It is necessary to implement a nationwide antimicrobial resistance monitoring program in Colombia together with antimicrobial prescribing guidelines for pigs. The indiscriminate use of antimicrobials for growth promotion in the swine industry is clearly promoting widespread resistance and should be discontinued.

\section{Declarations}

\section{Acknowledgements}

The authors thank the Laboratorio de Diagnóstico Veterinario of the Facultad de Ciencias Agrarias of the Universidad de Antioquia that accepted to collaborate in this study and CIBAV.

\section{Funding}

This research was funded by CIBAV. The authors acknowledge the Strategy of Consolidation of Research Groups (CODI 2018-2019), Universidad de Antioquia (UdeA), Medellín, Colombia.

\section{Conflicts of interest}

The authors declare they have no conflicts of interest with regard to the work presented in this report.

\section{Author contribution}

Juan F Mantilla and David Gomez worked on aspects involving methodology and statistical analysis. David Villar wrote and prepared the manuscript. Jenny Chaparro and Juana L Vidal contributed with their scientific advice for publication and revision. All authors have read and agreed to the published version of the manuscript. 


\section{References}

Aidara-Kane A, Angulo FJ, Conly JM, Minato Y, Silbergeld EK, McEwen SA, Collignon PJ. World Health Organization (WHO) guidelines on use of medically important antimicrobials in food-producing animal. Antimicrob Resist Infect Control 2018; 7: 7. DOI: https://doi.org/10.1186/s13756-017-0294-9

Angulo FJ, Nunnery JA, Bair HD. Antimicrobial resistance in zoonotic enteric pathogens. Rev Sci Tech 2004; 23(2): 485-496. DOI: https://doi.org/10.20506/rst.23.2.1499

Arenas NE, Moreno-Melo V. Livestock production and emergency antibiotic resistance in Colombia: systematic review. Infectious 2018; 22(2): 110-119. DOI: https://doi.org/10.22354/in.v22i2.717

Ayala-Romero C, Ballen-Parada C, Rico-Gaitán M, Chamorro-Tobar I, Zambrano-Moreno D, Poutou-Piñales R, Carrascal-Camacho A. Prevalence of Salmonella spp. in mesenteric pig's ganglia at Colombian slaughter houses. Rev MVZ Córdoba 2018; 23(1): 6474-6486. DOI: https://doi.org/10.21897/rmvz.1242

Belluco S, Barco L, Roccato A, RicciA. Variability of Escherichia coli and Enterobacteriaceae counts on pig carcasses: A systematic review. Food Control 2005; 55: 115-126. DOI: https://doi.org/10.1016/j.foodcont.2015.02.042

Campos J, Mourão, Peixe L, Antunes P. Nontyphoidal Salmonella in the pig production chain: a comprehensive analysis of its impact on human health. Pathogens 2019; 8(1): 19. DOI: https://doi.org/10.3390/pathogens8010019

CLSI. Performance Standards for Antimicrobial Dick and Dilutions Susceptibility Test for Bacteria Isolated from Animals. 4th Edition. CLSI Supplement Vet08. Wayne, PA, 2018.

Cutler R, Gleeson B, Page S, Norris J, Browning G. Antimicrobial prescribing guidelines for pigs. Aust Vet J 2020; 98: 105-134. DOI: https://doi.org/10.1111/avj.12940
De Briyne N, Atkinson J, Pokludová L, Borriello SP. Antibiotics used most commonly to treat animals in Europe. Vet Rec 2014; 174(13): 325. DOI: https://doi.org/10.1136/vr.102462

European Food Safety Authority (EFSA). The European Union summary report on trends and sources of zoonoses, zoonotic agents and foodborne outbreaks in 2011. EFSA J 2013; 11: 3129. DOI: https://doi.org/10.2903/j.efsa.2013.3129

European Food Safety Authority (EFSA). The European Union summary on antimicrobial resistance in zoonotic and indicator bacteria from humans, animals and food in 2017. EFSA J 2019; 17(2): e05598. DOI: https://doi.org/10.2903/j.efsa.2018.5500

Giraldo-Cardona JP, Gualdrón-Ramírez D, Chamorro-Tobar I, Pulido-Villamarín A, Santamaría-Durán N, CastañedaSalazar R, Zambrano-Moreno C, CarrascalCamacho AK. Salmonella spp. prevalence, antimicrobial resistance and risk factor determination in Colombian swine farms. Pesq Vet Bras 2019; 39(10). DOI: https://doi.org/10.1590/1678-5150-pvb-6156

Haley CA, Dargatz DA, Bush EJ, Erdman MM, Ferdorka-Cray PJ. Salmonella prevalence and antimicrobial susceptibility from the National Animal Health Monitoring System Swine 2000 and 2006 Studies. J Food Prot 2012; 75(3): 428-436. DOI: https://doi.org/10.4315/0362-028X.JFP-11-363

Kadykalo S, Anderson MEC, Alsop JE. Passive surveillance of antimicrobial resistance in Salmonella and Escherichia coli isolates from Ontario livestock, 2007-2015. Can Vet J 2018; 59: 617-622. [access December 15 ${ }^{\text {th }}, 2020$ ] URL: https://www.ncbi.nlm.nih.gov/pmc/articles/ PMC5949941/pdf/cvj 06 617.pdf

Karp BE, Tate H, Plumblee JR, Dessai U, Whichard JM, Thacker EL, Hale KR, Wilson W, Friedman CR, Griffin PM, McDermott PF. 2017. National Antimicrobial Resistance Monitoring System: two decades of advancing public health through surveillance of antimicrobial resistance. 
Foodborne Pathog Dis 2017; 14(10): 545-557. DOI: https://doi.org/10.1089/fpd.2017.2283

Kidsley AK, Abraham S, Bell JM, O’Dea M, Laird TJ, Jordan D, Mitchell P, McDevitt CA, Trott DJ. Antimicrobial susceptibility of Escherichia coli and Salmonella spp. isolates from healthy pigs in Australia: results of a Pilot national survey. Front Microbial 2018; 9: 1207. DOI: https://doi.org/10.3389/fmicb.2018.01207

Lester SC, Pla MP, Wang F, Perez-Schael I, Jiang H, O'Brien TF. The carriage of Escherichia coli resistanttoantimicrobialagentsbyhealthychildren in Boston, in Caracas, Venezuela, and in Qin Pu, China. NEngl J Med 1990; 323(5): 285-289. DOI: https://doi.org/10.1056/NEJM199008023230501

Magiorakos AP, Srinivasan A, Carey RB, Carmeli Y, Falagas ME, Giske CG, Harbarth S, Hindler JF, Kahlmeter G, OlssonLiljequist B, Paterson DL, Rice LB, Stelling J, Struelens MJ, Vatopoulos A, Weber JT, Monnet DL. Multidrug-resistant, extensively drug-resistant and pandrug-resistant bacteria: an international expert proposal for interim standard definitions for acquired resistance. Clin Microbiol Infect Dis 2012; 18: 268-281. DOI: https://doi.org/10.1111/j.1469-0691.2011.03570.x

Magnusson U, Sternberg S, Eklund G, Rozstalnyy A. Prudent and efficient use of antimicrobials in pigs and poultry. FAO Animal Production and Health Manual 23. Rome. FAO, 2019.

Nijsten R, London N, Van den Bogaard A, Stobberingh E. In vitro transfers of antibiotic resistance between faecal Escherichia coli strains isolated from pig farmers and pigs. J Antimicrob Chemother 1996; 37(6): 1141-1154. DOI: https://doi.org/10.1093/jac/37.6.1141

Van den Bogaard AE, London N, Stobberingh EE. Antimicrobial in pig faecal samples from The Netherlands (five abattoirs) and Sweden. J Antimicrob Chemother 2000; 45: 663-671. DOI: https://doi.org/10.1093/jac/45.5.663

WHO Guidelines on Use of Medically Important Antimicrobials in Food-Producing Animals. 2017. Geneva: World Health Organization. [access December $\left.15^{\text {th }}, 2020\right]$ URL: https://www.ncbi.nlm.nih.gov/books/NBK487966/ 